\title{
Lack of a-disintegrin-and-metalloproteinase ADAM10 leads to intracellular accumulation and loss of shedding of the cellular prion protein in vivo
}

\author{
Hermann C Altmeppen ${ }^{1}$, Johannes Prox², Berta Puig ${ }^{1}$, Mark A Kluth ${ }^{3}$, Christian Bernreuther ${ }^{1}$, Dana Thurm', \\ Ellen Jorissen ${ }^{4,5}$, Bettina Petrowitz ${ }^{6}$, Udo Bartsch ${ }^{6}$, Bart De Strooper ${ }^{4,5}$, Paul Saftig $^{2}$ and Markus Glatzel ${ }^{1 *}$
}

\begin{abstract}
Background: The cellular prion protein ( $\mathrm{PrP}^{\mathrm{C}}$ ) fulfils several yet not completely understood physiological functions. Apart from these functions, it has the ability to misfold into a pathogenic scrapie form $\left(\operatorname{PrP}^{\mathrm{SC}}\right)$ leading to fatal transmissible spongiform encephalopathies. Proteolytic processing of $\operatorname{PrP}^{\complement}$ generates $\mathrm{N}$ - and $\mathrm{C}$-terminal fragments which play crucial roles both in the pathophysiology of prion diseases and in transducing physiological functions of $\operatorname{PrP}{ }^{C}$. A-disintegrin-and-metalloproteinase 10 (ADAM10) has been proposed by cell culture experiments to be responsible for both shedding of $\operatorname{PrP}^{C}$ and its $\alpha$-cleavage. Here, we analyzed the role of ADAM10 in the proteolytic processing of PrPC in vivo.
\end{abstract}

Results: Using neuron-specific Adam10 knockout mice, we show that ADAM10 is the sheddase of $\operatorname{PrPC}$ and that its absence in vivo leads to increased amounts and accumulation of PrPC in the early secretory pathway by affecting its posttranslational processing. Elevated $\operatorname{PrP}^{C}$ levels do not induce apoptotic signalling via p53. Furthermore, we show that ADAM10 is not responsible for the $\alpha$-cleavage of $\operatorname{Pr} P^{C}$.

Conclusion: Our study elucidates the proteolytic processing of $\mathrm{PrP}^{C}$ and proves a role of ADAM10 in shedding of $\mathrm{PrP}^{\mathrm{C}}$ in vivo. We suggest that ADAM10 is a mediator of $\operatorname{PrP}^{C}$ homeostasis at the plasma membrane and, thus, might be a regulator of the multiple functions discussed for $\operatorname{PrP}^{C}$. Furthermore, identification of ADAM10 as the sheddase of $\mathrm{PrP}^{C}$ opens the avenue to devising novel approaches for therapeutic interventions against prion diseases.

\section{Background}

The cellular prion protein $\left(\operatorname{PrP}^{\mathrm{C}}\right)$, a glycosylphosphatidylinositol (GPI)-anchored membrane protein, plays a dual role in the biology of the brain. It is the substrate for the generation of its pathological isoform $\left(\mathrm{PrP}^{\mathrm{Sc}}\right)$, which is the principal component of prion infectivity and causally involved in the pathophysiology of prion diseases. On the other hand, it accomplishes a multitude of physiological functions ranging from neurogenesis to myelin maintenance $[1,2]$. Proteolytic processing of $\operatorname{PrP}^{C}$ generating $\mathrm{N}$ - and $\mathrm{C}$-terminal cleavage products as well as shed full length $\operatorname{Pr} \mathrm{P}^{\mathrm{C}}$, is critically involved in the above mentioned physiological and pathophysiological aspects

\footnotetext{
* Correspondence: m.glatzel@uke.de

${ }^{1}$ Institute of Neuropathology, University Medical Center Hamburg-Eppendorf, D-20246 Hamburg, Germany

Full list of author information is available at the end of the article
}

[2-4]. For instance, a membrane-bound, C-terminal fragment of $\operatorname{PrP}^{C}$ is essential for myelin maintenance, and shed GPI-anchorless $\operatorname{PrP}^{\mathrm{Sc}}$ modulates prion neuroinvasion and prion disease phenotypes $[2,5]$. While $\beta$-cleavage is mainly observed under pathological conditions, key proteolytic processing of $\mathrm{PrP}^{\mathrm{C}}$ under physiological conditions includes $\alpha$-cleavage resulting in a membranebound, $\mathrm{C}$-terminal $(\mathrm{C} 1)$ and a soluble, $\mathrm{N}$-terminal (N1) fragment, and ectodomain shedding of $\operatorname{PrP}^{\mathrm{C}}$, releasing a GPI-anchorless form into the extracellular space [6-10] (Figure 1). A number of target proteases have been implicated in $\alpha$-cleavage and ectodomain shedding of $\operatorname{PrP}^{\mathrm{C}}$ under in vitro conditions with a-disintegrin-andmetalloproteinase (ADAM) 10 and ADAM17 as prime candidates for both cleavage events $[8,10]$.

ADAM10 mediates the shedding of several surface proteins in close proximity to the cellular membrane. 


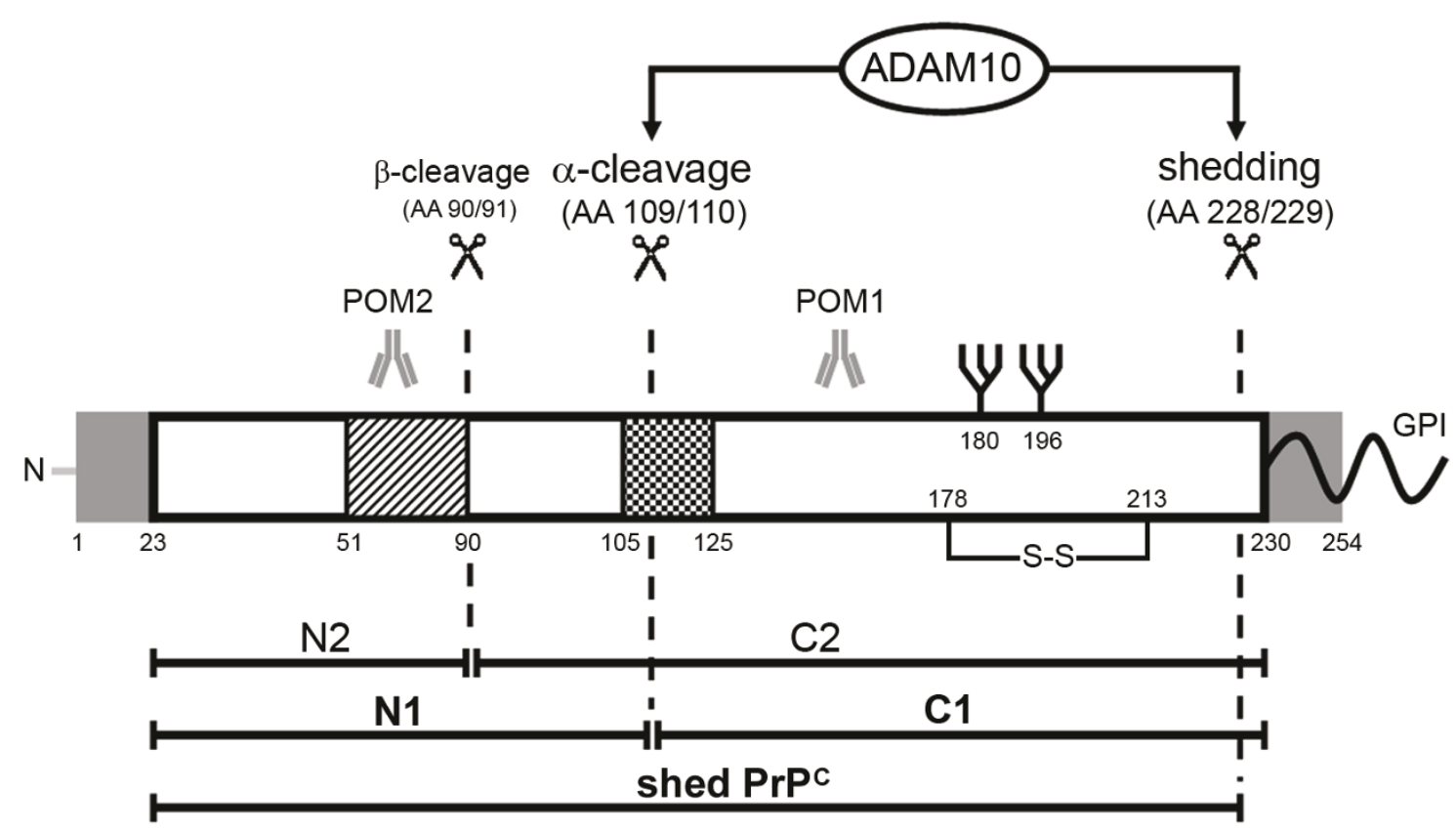

Figure 1 Proteolytic cleavage of $\mathrm{PrP}^{\mathrm{C}}$. After cleavage of the N-terminal and GPI anchor signal peptides (grey), mature membrane-bound PrPC can undergo at least three different proteolytic cleavage events (scissors) in addition to phospholipase $C$ cutting within its GPI anchor. While $\beta$ cleavage is mainly observed under pathological conditions, a role of ADAM10 is discussed in the context of both, constitutive $\alpha$-cleavage and shedding of $\operatorname{PrPC}$. The resulting fragments are shown underneath. Striped box: octameric repeat region; checked box: hydrophobic core domain. Epitopes of $\mathrm{PrP}^{\mathrm{C}}$ specific monoclonal antibodies POM1 and POM2 used in this study are indicated.

Substrates of ADAM10 in the brain include ephrins [11-13], neuronal adhesion molecule [14], N-cadherin [15], and the Notch receptor [16-19]. Initially demonstrated in cell culture experiments, ADAM10 has recently been identified as the $\alpha$-secretase of the amyloid precursor protein (APP) in vivo [20-23]. Involvement of ADAM10 in $\alpha$-cleavage and shedding of $\operatorname{PrP}^{C}$ has been studied in cell culture leading to some controversy $[8,10]$. Furthermore, a complete Adam10 knockout in mice resulted in early embryonic lethality making it impossible to study its influence on neuronal $\operatorname{PrP}^{C}$ processing in vivo [18]. This problem was overcome by the recent generation of a conditional, neuron-specific Adam10 knockout mouse (hence ADAM10 cKO or A10 cKO) [21]. Here, we used these ADAM10 cKO mice to study the effects of ADAM10 on proteolytic processing of $\operatorname{PrP}^{\mathrm{C}}$. We show that ADAM10 is responsible for ectodomain shedding of $\operatorname{PrP}^{\mathrm{C}}$ and that its absence results in $\operatorname{PrP}^{\mathrm{C}}$ accumulation in the early secretory pathway. Additionally, we demonstrate that ADAM10 is not responsible for $\alpha$-cleavage of $\operatorname{PrP}^{\mathrm{C}}$.

\section{Results}

\section{Lack of ADAM10 leads to posttranslational increase of PrPC}

Indirect evidence suggested that ADAM10 modulates $\operatorname{PrP}^{\mathrm{C}}$ levels [24]. A recently published, novel conditional knockout model lacking ADAM10 specifically in neurons allowed us to assess this notion in vivo [21]. Here, we used primary neurons and brain sections of ADAM10 cKO mice at embryonic day 14 (E14) to investigate the expression and localisation of $\operatorname{PrP}^{\mathrm{C}}$. Lack of ADAM10 resulted in increased levels of $\operatorname{PrP}^{C}$ as shown by Western blot analysis (Figure 2A). After quantification, $\operatorname{PrP}^{\mathrm{C}}$ amounts were increased by a factor of 1.94 (standard error of mean, SEM: 0,096) when compared to $\operatorname{PrP}^{\mathrm{C}}$ levels in neuronal lysates derived from age-matched wildtype embryos (set as one), with NestinCre-negative littermates (Controls) showing values of 1.19 (SEM: 0,117). Thus, $\operatorname{PrP}^{\mathrm{C}}$ levels were increased by $63 \%$ in ADAM10 cKO compared to littermate controls and differences were significant $(p=0,0013)$. Assessment of the contribution of di-, mono- and unglycosylated $\operatorname{PrP}^{C}$ to the total signal of $\operatorname{PrP}^{C}$ in Western blot analysis of ADAM10 $\mathrm{cKO}$ and control neurons revealed comparable glycoprofiles showing that ADAM10-related $\operatorname{PrP}^{\mathrm{C}}$ increase did not alter the extent of glycosylation of $\mathrm{PrP}^{\mathrm{C}}$ (data not shown). In accordance with published data, morphological analysis of ADAM10 cKO mice and controls at E14 did not show alterations in the gross cortical organisation [21]. An enhanced immunosignal for $\operatorname{PrP}^{\mathrm{C}}$ was observed in all cortical and subcortical regions (Figure $2 \mathrm{~B}$ ) as well as in the spinal cord including sensory ganglia when compared to littermate controls with a staining pattern showing increased signal 
A
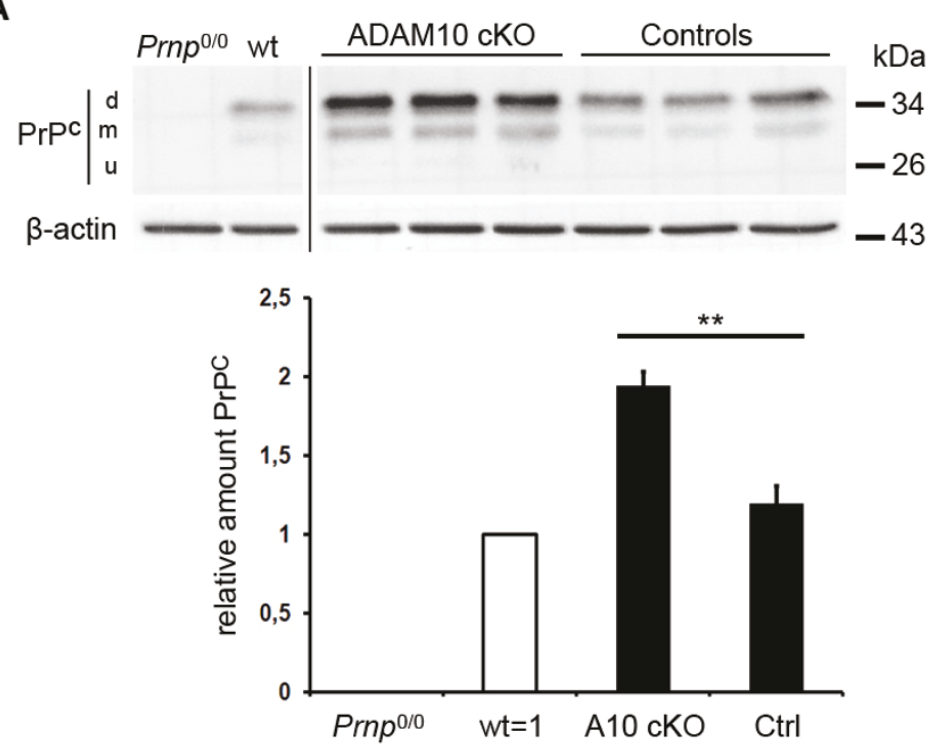

\section{B}

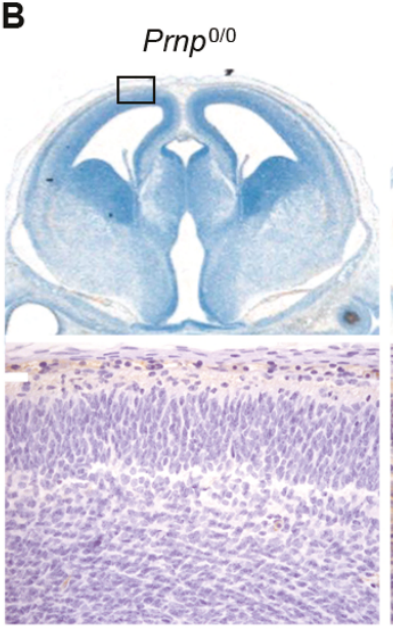

C

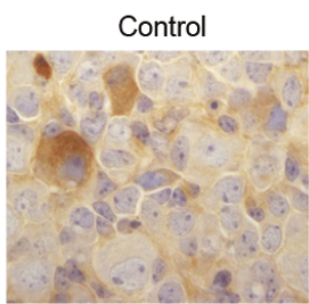

ADAM10 cKO

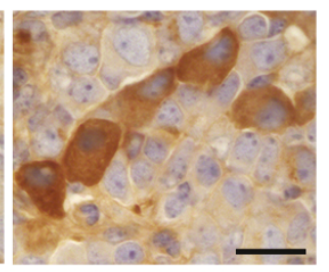

Control
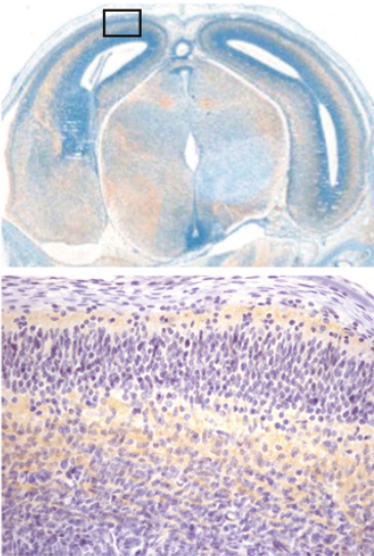

ADAM10 cKO
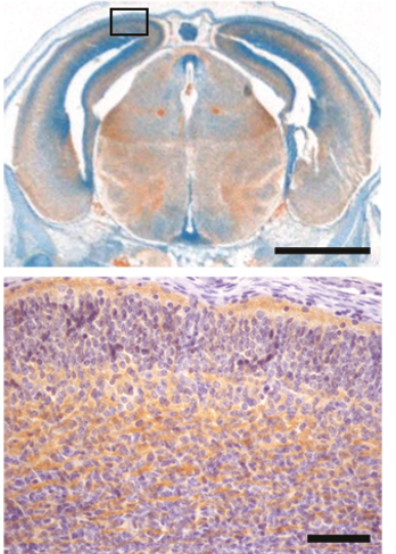

D

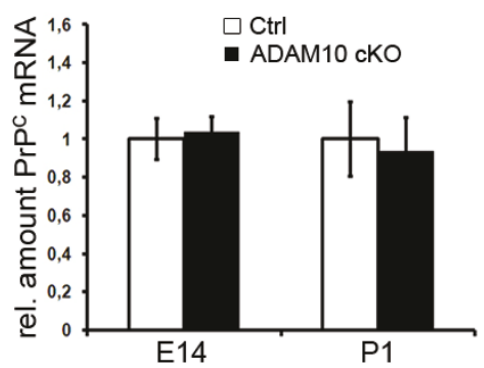

Figure 2 Increased amounts of PrP ${ }^{C}$ but unaltered mRNA levels in ADAM10 cKO mice. (A) Western blot analysis for PrP ${ }^{C}$ in primary neurons of Prnp ${ }^{0 / 0}$, wt, ADAM10 cKO and Nestin-Cre-negative littermate controls (all from E14 embryos). Quantification of PrPC amounts shows a statistically significant increase of PrPC in ADAM10 CKO neurons compared to littermate controls $(p=0,0013)$. All samples were normalized to wildtype which was set to one ( $n=3$ for wt and Prnp ${ }^{0 / 0} ; n=5$ for $A 10$ CKO and $\left.C t r l\right)(d, m, u=d i-$, mono-, unglycosylated PrPC; representative blot is shown). Immunohistochemical staining of $\mathrm{PrP}^{\mathrm{C}}$ in brains (B) and dorsal root ganglia (C) of E14 ADAM10 CKO mice and littermate controls shows enhanced immunosignal throughout the entire central nervous system with some degree of variation between individual neurons in ADAM10 CKO mice (C, scale bar: $20 \mu \mathrm{m}$ ). Brain of an age-matched Prnp ${ }^{0 / 0}$ mice was taken as negative control in B. (B, upper row: whole brain section, scale bar: $500 \mu \mathrm{m}$; bottom row: magnification of inserts, scale bar: $50 \mu \mathrm{m}$ ). (D) Quantitative RT-PCR for PrPC mRNA in brain homogenates of ADAM10 cKO and wildtype littermate controls shows no significant difference in expression levels between genotypes at E14 $(n=4)$ and P1 $(n=3)$. 
intensity in neurons of the central (Figure 2B) and peripheral nervous system (Figure 2C). Since we were interested in defining whether the increase in $\mathrm{PrP}^{\mathrm{C}}$ is due to transcriptional upregulation or due to posttranslational mechanisms, we quantified neuronal $\operatorname{PrP}^{C}$ mRNA levels by quantitative RT-PCR. No significant differences were detectable between wildtype littermate controls (set as one) and ADAM10 cKO neurons when assessed at E14 (A10 cKO: relative value $=1,037 ; \mathrm{SEM}=0,078 ; \mathrm{SEM}$ $\mathrm{Ctrl}=0,160 ; p=0,79)$ or postnatal day 1 (A10 cKO: rel. value $=0,935 ; \operatorname{SEM}=0,175 ;$ SEM Ctrl $=0,195 ; p=$ 0,82 ) (Figure 2D). Thus, increased $\operatorname{PrP}^{C}$ levels in brains and primary neurons of ADAM10 cKO mice are not caused by transcriptional upregulation but are rather due to posttranslational mechanisms.

\section{Lack of ADAM10 leads to accumulation of PrP ${ }^{C}$ in the early secretory pathway}

$\operatorname{PrP}^{C}$ is present both in intracellular compartments and on the plasma membrane. Thus, we were interested in examining the subcellular distribution of $\operatorname{PrP}^{\mathrm{C}}$ and in locating its increase in ADAM10 cKO compared to wildtype littermate neurons. To this aim, we performed confocal and spinning disc immunofluorescence microscopy using a $\operatorname{PrP}^{\mathrm{C}}$-specific antibody. Staining intensities of $\operatorname{PrP}^{C}$ at the plasma membrane appeared unaltered in ADAM10 cKO neurons when compared to controls (data not shown). However, in permeabilized control neurons, $\operatorname{PrP}^{\mathrm{C}}$ was localized in vesicular structures that were evenly distributed within the soma, whereas in ADAM10 cKO neurons, dense $\operatorname{PrP}^{\mathrm{C}}$ accumulations were found in intracellular compartments adjacent to the nucleus and along neuronal processes (Figure 3A). To determine the localization of these dense $\operatorname{PrP}^{\mathrm{C}}$ accumulations in more detail we performed co-stainings of $\operatorname{PrP}^{C}$ with organelle markers in ADAM10 cKO neurons and controls. Control neurons showed a partial, vesicular colocalization with all three markers, reflecting the biosynthesis, trafficking and degradation of $\operatorname{Pr} \mathrm{P}^{\mathrm{C}}$. Again, dense aggregates of $\operatorname{PrP}^{C}$ were only found in ADAM10 cKO neurons. These accumulations of $\operatorname{PrP}^{\mathrm{C}}$ colocalized with ER marker PDI and with Golgi marker GM130 (Figure 3B). No significant colocalization of dense $\mathrm{PrP}^{\mathrm{C}}$ accumulations, but a partial, vesicular colocalization of $\mathrm{PrP}^{\mathrm{C}}$ with lysosomal marker LAMP1 was found, reflecting the physiological turnover of $\operatorname{PrP}^{\mathrm{C}}$. These findings identify retention of $\operatorname{PrP}^{C}$ within the early secretory pathway rather than an interrupted degradation as the cause for increased $\operatorname{PrP}^{\mathrm{C}}$ levels seen in the absence of ADAM10.

\section{Expression and activation of p53 is not altered by increased levels of PrP ${ }^{C}$ in ADAM10 cKO}

Increased expression of $\operatorname{PrP}^{C}$ has been shown to induce p53-related pathways $[25,26]$. Therefore, we decided to investigate p53-related signalling in our model of ADAM10-related $\operatorname{PrP}^{\mathrm{C}}$ increase. Interestingly, we did not observe any evidence for induction of p53 at the protein level by Western blot analysis of neuronal lysates (Figure 4A). These data were confirmed by quantitative RT-PCR for p53 mRNA where there was no significant difference between ADAM10 cKO and littermate controls (set as one) when assessed at E14 (A10 cKO: rel. value $=1,07$; $\mathrm{SEM}=0,13$; SEM Ctrl $=$ 0,$16 ; p=0,75$ ) and P1 (A10 cKO: rel. value = 1,24; SEM $=0,16$; SEM Ctrl $=0,17 ; p=0,37$ ) (Figure 4B). In order to study a possible regulatory influence of increased $\operatorname{PrP}^{\mathrm{C}}$ on p53-dependent signalling, we also analyzed mRNA levels of Mdm2 (Figure 4B) and p21 (encoded by the Cdkn1a gene; data not shown), two essential coregulated targets in p53-related pathways [27]. No significant differences between neurons of ADAM10 cKO and littermate controls were detected (Mdm2 at E14: A10 cKO: rel. value $=1,38 ;$ SEM $=0,39 ;$ SEM Ctrl = 0,24; $p=0,44 / \mathrm{Mdm} 2$ at P1: $\mathrm{A} 10 \mathrm{cKO}$ : rel. value = 1,16; SEM $=0,22$; SEM Ctrl $=0,11 ; p=0,56)$. Thus, an ADAM10-related increase in $\operatorname{PrP}^{C}$ unlikely leads to the activation of p53-related pathways.

\section{$\alpha$-cleavage of PrPC in ADAM10 cKO mice}

It was previously suggested that ADAM10 is responsible for the $\alpha$-cleavage of $\operatorname{PrP}^{\mathrm{C}}$, giving rise to the membranebound $\mathrm{C} 1$ and the soluble N1 fragment (Figure 1) $[8,9]$. Our ADAM10 cKO mice allowed us to investigate this hypothesis in primary neurons and total brain homogenates. First, we analyzed via immunoblotting the Adam10 deletion efficiency in neuronal lysates from ADAM10 cKO, ADAM10 littermate controls, wildtype, tga20, and $\operatorname{Prnp}^{0 / 0}$ mice (Figure 5A). ADAM10 cKO neurons showed a nearly complete loss of ADAM10 with heterozygous littermates (A10 het.) showing a reduction in the expression of both premature (pADAM10) and mature ADAM10 (mADAM10) when compared to Nestin-Cre-negative littermate controls (Ctrl), indicating a dose-dependency in gene expression (Figure 5A; lanes 4-6). The relative increase of pADAM10 in wildtype neurons was most likely due to differences in the efficiency of neuronal lysis and was not seen in neuronal lysates from different wildtype mice (Additional file 1A). Analysis further revealed that lack $\left(P r n p^{0 / 0}\right)$ or transgenic overexpression of $\operatorname{PrP}^{\mathrm{C}}(\operatorname{tga} 20)$ did not modulate the levels of PADAM10 or MADAM10. Again, Western blot analysis for $\operatorname{PrP}^{C}$ confirmed the increase of $\mathrm{PrP}^{\mathrm{C}}$ in ADAM10 cKO neurons described above. Upon deglycosylation with PNGase F, C1 became detectable as a band of approx. $16 \mathrm{kDa}$. We could detect $\mathrm{C} 1$ irrespectively of the ADAM10 status of neurons (Figure 5A; complete Western blot of PNGase F digestion is shown in Additional file 1B). In fact, C1 signal strength was stronger in tga 20 and ADAM10 cKO neurons arguing 
A
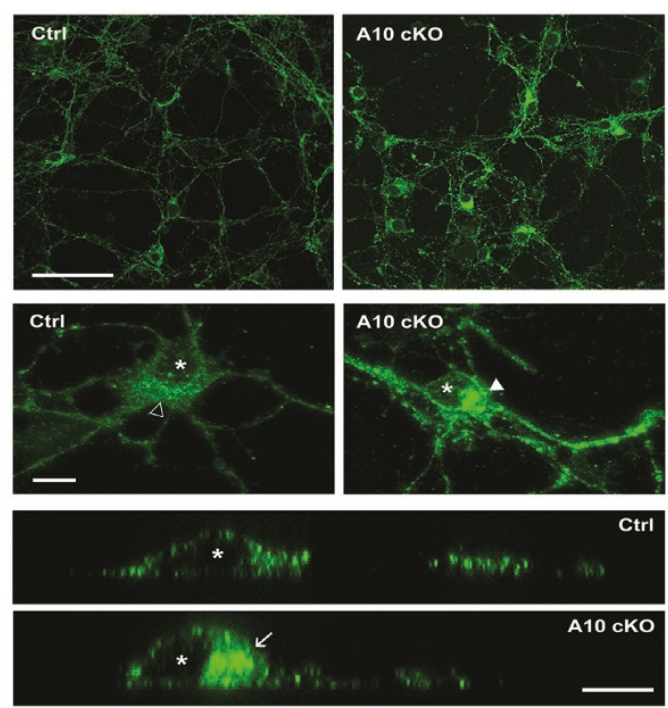

B
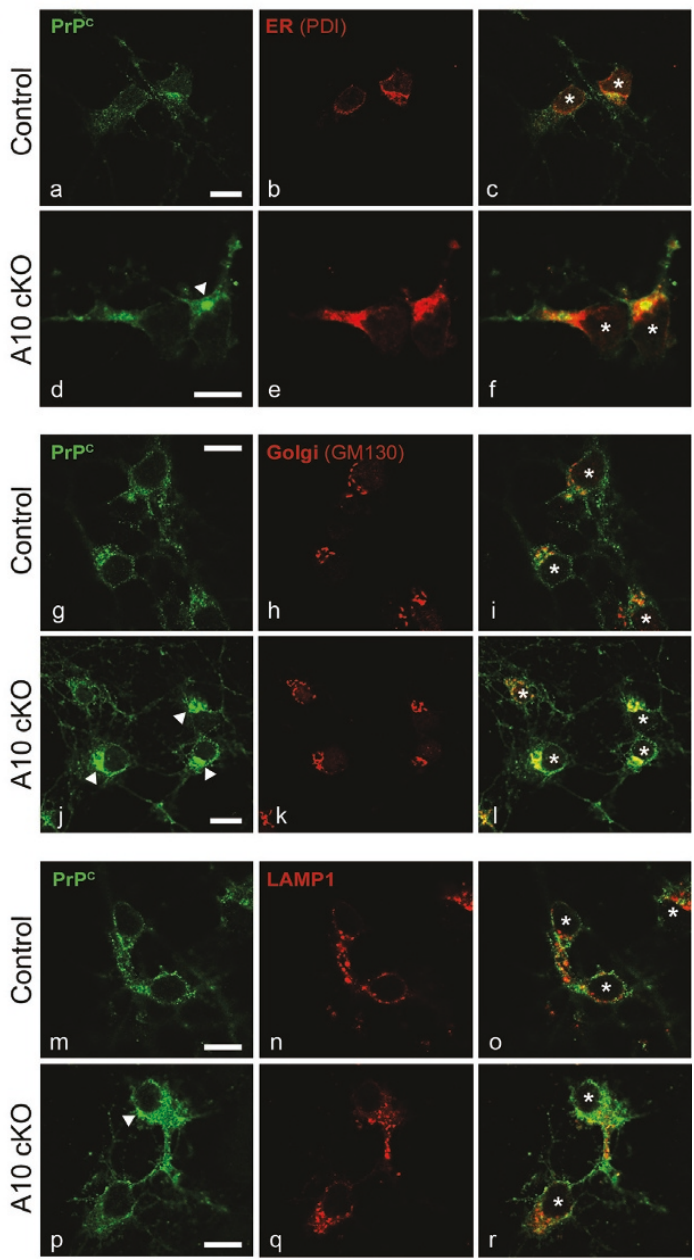

Figure 3 PrPC accumulates in intracellular compartments in ADAM10 cKO neurons. (A) Confocal (upper two rows; scale bar overview: 100 $\mu \mathrm{m}$, scale bar single neuron: $10 \mu \mathrm{m}$ ) and spinning disc (lower two rows; scale bar YZ-sections: $10 \mu \mathrm{m}$ ) immunofluorescence microscopy for PrPC in permeabilized wildtype neurons (Ctrl) shows PrPC in evenly distributed vesicular structures (open arrowhead). In ADAM10 cKO neurons, dense $\operatorname{PrP}^{C}$ accumulations are detectable adjacent to the nucleus (filled arrowhead) and in neuronal processes. YZ-sections through individual neurons confirm these findings (arrow for $\operatorname{PrP}^{C}$ accumulation in ADAM10 CKO). Asterisks mark nuclei. (B) Confocal microscopic analysis of co-stainings of $\operatorname{PrP}^{C}$ (left column) with intracellular organelle marker proteins (middle column) in wildtype littermate (Control) and ADAM10 cKO neurons.

Overlays are shown in the right column. Accumulations of $\operatorname{PrP}^{C}$ are only found in ADAM10 CKO neurons (filled arrowheads in $d, j$, and $p$ ) and colocalize with protein disulfide isomerase (PDI) used as marker for ER (e, f) and Golgi marker GM130 (k, I). Partial colocalization of PrPC with the lysosomal marker LAMP1 is detectable in vesicular structures $(q, r)$. Scale bars represent $10 \mu \mathrm{m}$. Asterisks in overlays mark nuclei. 


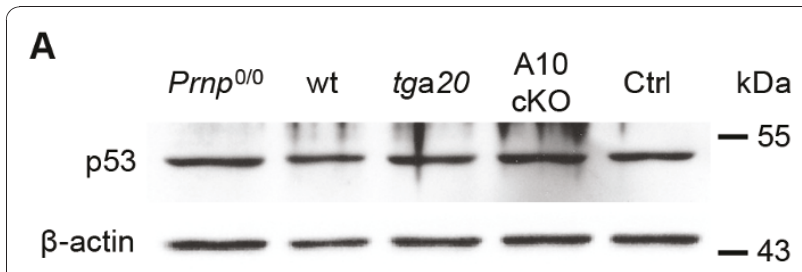

B

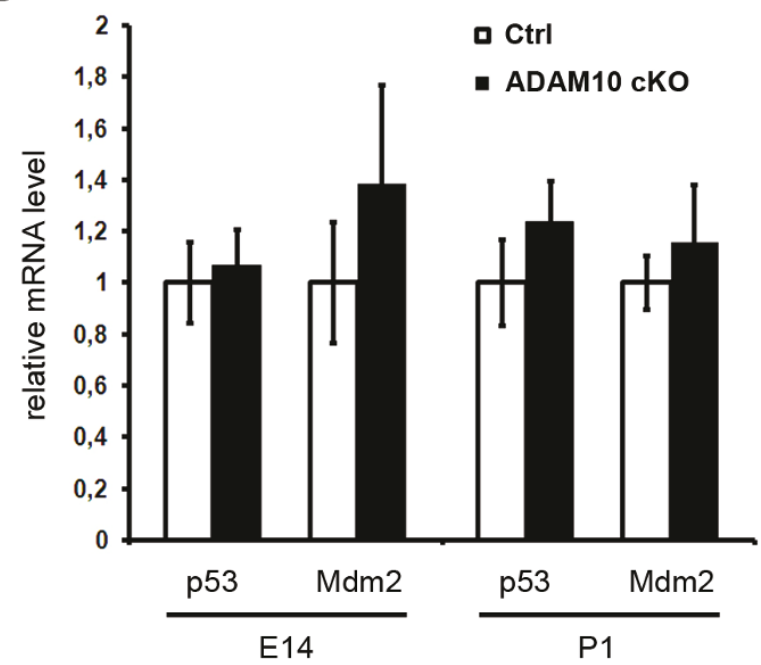

Figure 4 No induction of p53 or p53-regulated pathways in ADAM10 cKO. (A) Western blot analysis in lysates of primary neurons from Prnp ${ }^{0 / 0}$, wt, tga20, ADAM10 CKO and littermate controls (all from E14 embryos) shows comparable protein amounts of p53. (B) Using quantitative RT-PCR, relative mRNA levels of p53 and its downstream signalling target $\mathrm{Mdm} 2$ were determined in brain homogenates of ADAM10 CKO mice and wildtype littermates controls at E14 $(n=4)$ and P1 $(n=3)$. No significant differences in expression levels of $\mathrm{p} 53$ and Mdm2 were observed between genotypes at both ages (E14: $p=0,75$ for $p 53$ and $p=0,44$ for Mdm2; P1: $p=0,37$ for $p 53$ and $p=0,56$ for Mdm2).

that the amount of $\operatorname{PrP}^{\mathrm{C}}$ rather than the presence of ADAM10 correlates with the appearance of C1. Increased levels of $\mathrm{PrP}^{\mathrm{C}}$ and $\mathrm{C} 1$ were also found in brain homogenates of ADAM10 cKO mice at E14 when compared to wildtype littermate controls (Figure 5B). Furthermore, the corresponding, soluble N1 fragment of approx. $11 \mathrm{kDa}$ was immunoprecipitated from supernatants of primary neurons and was present in all samples except for Prnp ${ }^{0 / 0}$ neurons (Figure 5C and Additional file $1 \mathrm{C}$ ). As with $\mathrm{C} 1$, the $\mathrm{N} 1$ fragment appeared to be increased in supernatants of ADAM10 cKO neurons when compared to wildtype controls. In summary, $\alpha$-cleavage occurs in the absence of ADAM10, challenging the role of ADAM10 in this processing step of $\operatorname{PrP}^{\mathrm{C}}$ in vivo.

\section{ADAM10 cKO mice do not shed PrP ${ }^{C}$}

ADAM10 plays important roles in regulated intramembrane proteolysis and in vitro studies suggest that
ADAM10 is involved in shedding of $\operatorname{PrP}^{\mathrm{C}}$ at the plasma membrane [10]. Here, we investigated this issue using ADAM10 cKO primary neurons and performing immunoprecipitations of shed $\mathrm{PrP}^{C}$ from conditioned media. Following SDS-PAGE and immunoblotting, we observed an almost complete lack of shed $\operatorname{PrP}^{\mathrm{C}}$ in culture supernatants from ADAM10 cKO neurons (Figure 6A; tga20: rel. value $=2,85 ; \mathrm{SEM}=0,49 ; \mathrm{A} 10 \mathrm{cKO}$ : rel. value =0,24; $\mathrm{SEM}=$ 0,08; Ctrl: rel. value $=1,07 ; \mathrm{SEM}=0,15 ; p=0,0026)$. An additional blot for shed $\operatorname{PrP}^{C}$ is shown in Additional file 1C). Immunoprecipitated shed $\operatorname{PrP}^{C}$ showed a slightly different running behaviour in gel electrophoresis when compared to $\mathrm{PrP}^{\mathrm{C}}$ in neuronal lysates. This shift of $2 \mathrm{kDa}$ reflects the truncation of shed $\operatorname{PrP}^{\mathrm{C}}$, which lacks the GPI anchor and two C-terminal amino acids. To determine whether the lack of shedding is directly linked to the absence of ADAM10, we carried out rescue experiments by expressing ADAM10 in neural stem (NS) cells derived from ADAM10 cKO mice, followed by neuronal differentiation. Importantly, re-expression of ADAM10 led to reappearance of shed $\mathrm{PrP}^{\mathrm{C}}$ in supernatants of neuronally differentiated NS cell cultures transfected with Adam10, but not in supernatants of mock-transfected control cultures (Figure 6B). Based on these results, we conclude that ADAM10 is both necessary and sufficient to release $\operatorname{PrP}^{\mathrm{C}}$ from the neuronal surface.

\section{Discussion}

$\operatorname{PrP}^{C}$ is in the focus of research because of its unique ability to act as an infectious agent in its misfolded form $[28,29]$. Furthermore, its physiological functions are manifold ranging from neurogenesis to binding of betaamyloid $[1,30]$. Both aspects are influenced by proteolytic processing of $\operatorname{PrP}^{\mathrm{C}}$ (Figure 1A; reviewed in [7]). Shedding at the plasma membrane, $\alpha$-cleavage within the hydrophobic core, and $\beta$-cleavage subsequent to the octameric repeat region have been described for $\operatorname{PrP}^{C}$ [6,8,31-33]. However, all studies aimed at identifying the respective proteases have been performed using cell lines. For $\alpha$-cleavage and shedding, the metalloproteinase ADAM10 has been suggested as the responsible protease [8-10]. Neuron-specific conditional ADAM10 knockout mice allowed us to address the role of ADAM10 for $\mathrm{PrP}^{\mathrm{C}}$ processing in vivo [21].

Since a causal relationship between ADAM10 levels and $\mathrm{PrP}^{\mathrm{C}}$ amounts has been postulated, we measured $\mathrm{PrP}^{\mathrm{C}}$ levels in ADAM10 cKO mice [24]. We found a significant increase in $\mathrm{PrP}^{\mathrm{C}}$ protein levels in ADAM10 cKO mice, while mRNA levels remained unaltered. Microscopic analysis showed an ADAM10-dependent intracellular accumulation of $\operatorname{PrP}^{C}$ in perinuclear compartments, but an unaltered expression pattern at the neuronal cell surface. This observation indicates that posttranslational mechanisms rather than transcriptional upregulation 


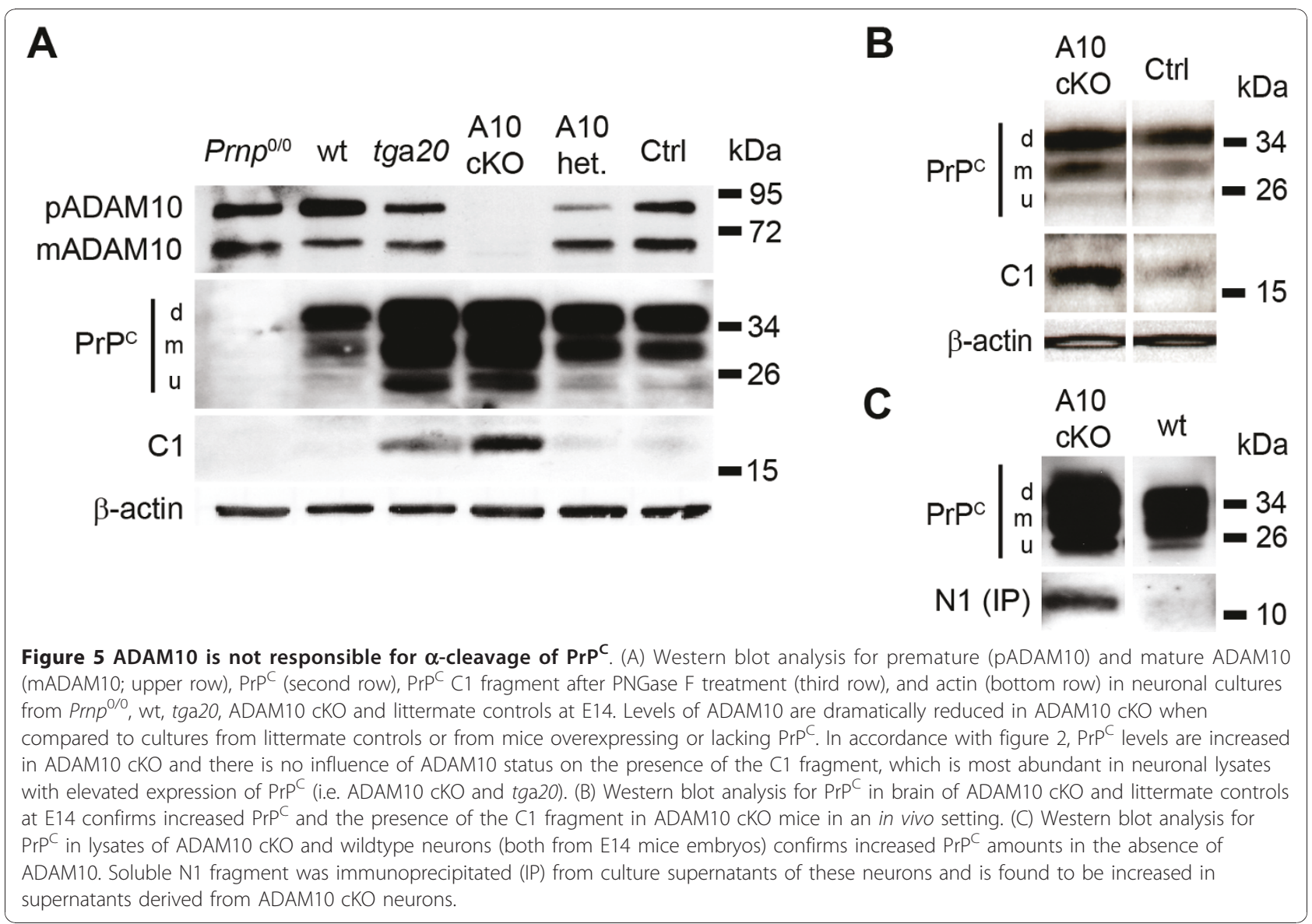

account for elevated $\operatorname{PrP}^{\mathrm{C}}$ levels in the absence of ADAM10 and contrasts a study where overexpression of ADAM10 led to downregulation of $\mathrm{PrP}^{\mathrm{C}}$ at the mRNA level [24]. Since we found $\operatorname{PrP}^{\mathrm{C}}$ accumulations to be located in the ER and Golgi apparatus, we postulate that $\mathrm{PrP}^{\mathrm{C}}$ is retained within these organelles in cells lacking ADAM10. In view of unaltered mRNA levels, constitutive biosynthesis in combination with the strong retention in the early secretory pathway seems to be the main reason for increased $\mathrm{PrP}^{\mathrm{C}}$ levels in ADAM10 cKO mice.

$\mathrm{PrP}^{\mathrm{C}}$ overexpression has been shown to downregulate beta-site APP-cleaving enzyme 1 (BACE1) in a glycosaminoglycan-dependent manner [34]. Interestingly, ADAM10 cKO mice show reduced APP-processing activity of BACE1 [21]. Thus, the data presented here provide a rationale for this phenomena linking ADAM10-related increase of $\mathrm{PrP}^{\mathrm{C}}$ to reduction of BACE1 activity.

The interaction of $\operatorname{PrP}^{\mathrm{C}}$ and $\mathrm{p} 53$ has been highlighted recently with overexpression of $\mathrm{PrP}^{\mathrm{C}}$ leading to induction of p53-dependent pro-apoptotic pathways and p53 controlling expression of $\operatorname{PrP}^{\mathrm{C}}$ via promoter transactivation $[25,26,35,36]$. In view of the fact that ADAM10 cKO mice die perinatally and show a degree of neurodegeneration that can only partially be explained by altered Notch signalling [21], $\operatorname{PrP}^{\mathrm{C}}$-related induction of p53-dependent apoptosis seemed an attractive mechanism to explain this phenotype, in particular because of the increased amount of $\operatorname{PrP}^{C}$ found in these animals. However, we were unable to detect any dysregulation of p53-related pathways in our ADAM10 cKO neurons, which is in contrast to the study by Liang et al. who found a link between inducible upregulation of $\operatorname{PrP}^{\mathrm{C}}$ and p53-dependent apoptosis [25,26,35,36]. Rather, our results are in line with a recent study showing cellular imbalance but unaltered p53 levels in response to $\mathrm{PrP}^{\mathrm{C}}$ overexpression [37]. A recently published model states that p53 transcription is upregulated by the formation of the amyloid intracellular domain (AICD) during presenilin-dependent $\gamma$-secretase cleavage of APP with increased p53 subsequently activating $\operatorname{PrP}^{C}$ transcription [36]. Since production of the APP C-terminal fragment as a prerequisite for AICD formation is reduced in ADAM10 cKO mice [21], our findings of unaltered $\operatorname{PrP}^{\mathrm{C}}$ and $\mathrm{p} 53$ mRNA levels fit into this concept.

The $\alpha$-cleavage of $\operatorname{PrP}^{C}$, which takes place in the late secretory pathway [38], has been shown to be of utmost 


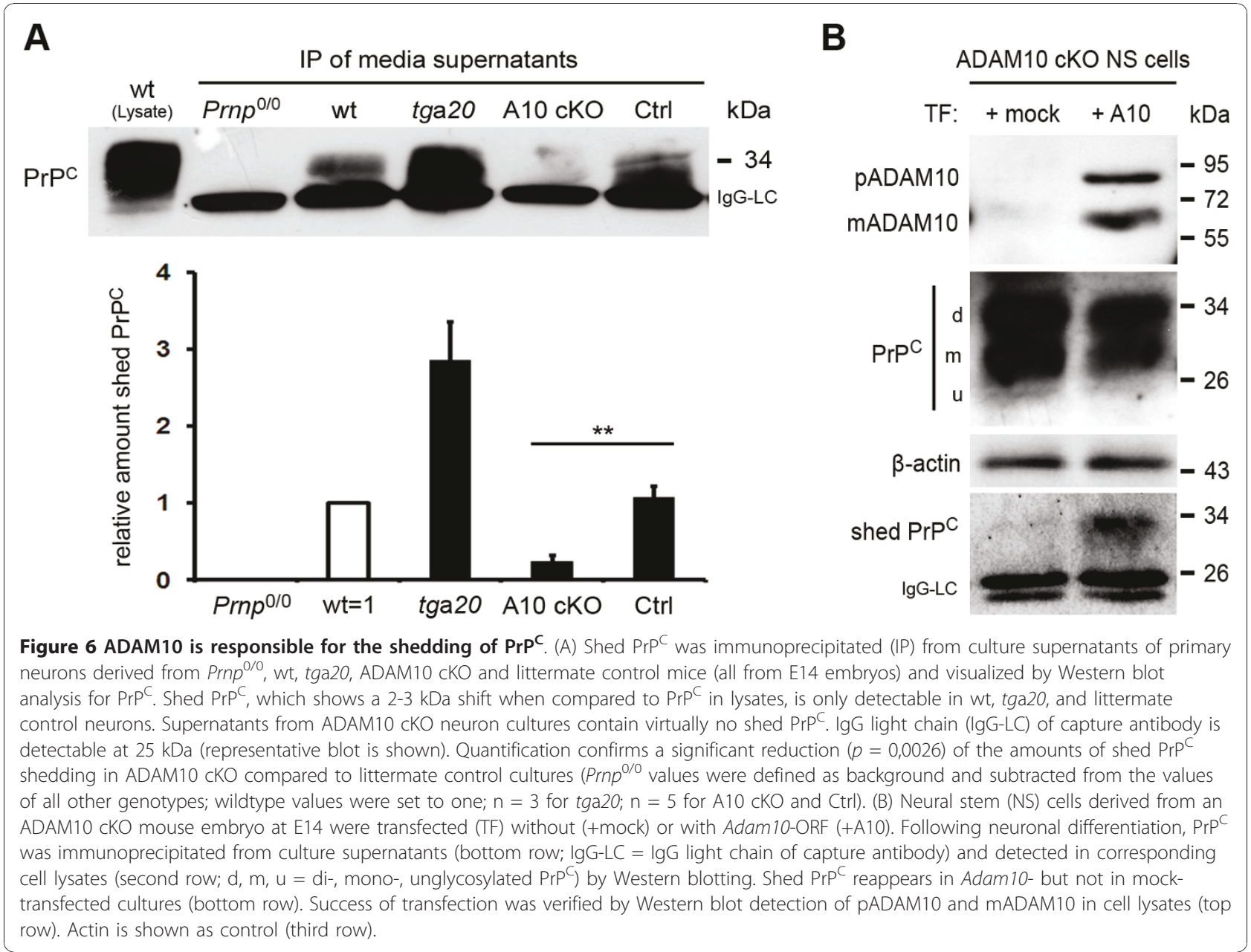

functional importance. Firstly, N-terminally truncated forms of $\operatorname{PrP}^{C}$ lead to neurodegeneration in transgenic mice [39-41]. Secondly, the N1 fragment can counteract experimentally induced p53-dependent caspase-3 activation in vitro and in vivo, indicating a neuroprotective function [42]. Thirdly, the corresponding C1 fragment was shown to act in trans on adjacent Schwann cells maintaining myelination [2], and it has been proposed to activate apoptotic pathways leading to neuronal death [3]. The $\alpha$-cleavage occurs within the hydrophobic core, one of the most highly conserved domains of $\operatorname{PrP}^{\mathrm{C}}$, which underlines the importance of this processing [43]. Thus, elucidating the nature of the responsible protease, recently termed $\alpha$-PrPase, will help in understanding the physiological functions of $\mathrm{PrP}^{\mathrm{C}}$ and the pathophysiology of prion disease $[6,44,45]$. Since ADAM10 was suggested to be the $\alpha$-PrPase $[8,9,46]$, we assessed this in our model. The fact that we found increased levels of $\mathrm{C} 1$ and N1 in primary neurons and total brain homogenates of ADAM10 cKO embryos clearly argues against involvement of ADAM10 in $\alpha$-cleavage of $\operatorname{PrP}^{C}$ with increased amounts of $\operatorname{PrP}^{\mathrm{C}}$ in ADAM10 cKO yielding elevated levels of $\mathrm{C} 1$ and N1. Although a varying PNGase F digestion efficiency could partially contribute to enhanced $\mathrm{C} 1$ presence in $\mathrm{A} 10 \mathrm{cKO}$ neurons compared to tga20 in Figure 5A, we speculate that ADAM10 negatively regulates $\alpha$-cleavage possibly by inhibiting the responsible protease. Our findings are in line with in vitro results of Taylor and colleagues, who were also unable to directly link ADAM10 expression or silencing to $\mathrm{C} 1$ prevalence [10]. Thus, the $\alpha$-PrPase, which has recently been shown to tolerate severe modifications within the $\operatorname{PrP}^{\mathrm{C}}$ sequence [45], still needs to be identified.

ADAM10 is the sheddase of a number of transmembrane proteins and was linked to constitutive shedding of $\operatorname{PrP}^{\mathrm{C}}$ using cell lines overexpressing $\operatorname{PrP}^{\mathrm{C}}[10,47]$. Here, we investigated the role of ADAM10 in $\mathrm{PrP}^{\mathrm{C}}$ processing in a physiological context in vivo. In agreement with in vitro data, we found an almost complete lack of $\mathrm{PrP}^{\mathrm{C}}$ shedding in ADAM10 cKO mouse neurons. Furthermore, genetic introduction of Adam10 into 
ADAM10 cKO NS cells rescued shedding activity. Thus, we were able to identify ADAM10 as the functionally relevant sheddase of $\operatorname{PrP}^{\mathrm{C}}$, which is further supported by the increase in $\operatorname{PrP}^{\mathrm{C}}$ protein levels in ADAM10 cKO mice discussed above. Based on our results, we propose a model where shedding by ADAM10 is a mechanism to regulate the $\operatorname{PrP}^{\mathrm{C}}$ amount at the cellular membrane. When shedding is impaired, the cell reacts with retention of $\operatorname{PrP}^{C}$ in the early secretory pathway rather than allowing it to accumulate at the plasma membrane. In view of the multiple functions discussed for $\operatorname{PrP}^{\mathrm{C}}$, our findings indicate the importance of tightly controlled amounts of $\operatorname{PrP}^{C}$ at the neuronal surface.

\section{Conclusion}

Our data show that ADAM10 does not perform $\alpha$-cleavage but shedding of $\operatorname{PrP}^{\mathrm{C}}$, with lack of ADAM10 activity leading to increased amounts of $\operatorname{PrP}^{\mathrm{C}}$ due to its retention within early secretory compartments. These data further underscore the physiological relevance of proteolytic processing of $\mathrm{PrP}^{\mathrm{C}}$ and shed light on the nature of the $\operatorname{PrP}^{\mathrm{C}}$-sheddase. Yet, its impact on the course of prion disease is not known in detail. While a recent in vitro study showed no shedding-dependent modulation of prion conversion [10], incubation times after scrapie inoculation were prolonged in mice overexpressing Adam10 [24]. Further studies of proteolytic processing of $\mathrm{PrP}^{\mathrm{C}}$ may provide novel approaches for therapeutic interventions against prion diseases.

\section{Methods}

\section{Generation of murine primary neuronal cultures}

Primary neurons were obtained from E14 embryos of Adam10 conditional knockout mice $\left(\operatorname{Adam} 10^{\mathrm{Fl} / \mathrm{Fl}} \mathrm{Nes}\right.$ tin-Cre-positive; ADAM10 cKO or A10 cKO) $[21,48]$. Adam $10^{F l /+}$ Nestin-Cre-positive (A10 heterozygous) and Adam $10^{F l /+}$ Nestin-Cre-negative (A10 wildtype control or Ctrl) embryos served as littermate controls. Further controls included prion protein knockout embryos (Prnp ${ }^{0 / 0}$; [49]), wildtype embryos (wt; C57BL/6), and prion protein overexpressing embryos (tga20; [50]). Briefly, embryonic brains were isolated, trypsinized, and cell suspensions were seeded on poly-L-lysine coated (Sigma) cell culture dishes (Sarstedt) in B-27 containing neurobasal medium (Invitrogen) as described previously [51]. Non-neuronal cells were eliminated by treatment with $5 \mu \mathrm{M}$ cytosine arabinoside (Sigma) $24 \mathrm{~h}$ after plating. After four days, primary neurons were cultivated for additional $24 \mathrm{~h}$ in medium lacking B-27. Culture supernatants were collected for immunoprecipitation experiments and cells were lysed for Western blot analysis as described below. All animal procedures were performed in accordance with the institutional guidelines from the animal facility of the University Medical Center Hamburg-Eppendorf.

\section{Immunoprecipitation of $\operatorname{PrP}^{\mathrm{C}}$ from conditioned media}

Protease inhibitor cocktail (PI; Roche) was added to the supernatants. After centrifugation for $5 \mathrm{~min}$ at $3,000 \times \mathrm{g}$ and $4^{\circ} \mathrm{C}$, volumes were normalized according to the total protein content of corresponding cell lysates (see below) and supernatants (approx. $4 \mathrm{ml}$ ) were concentrated by use of Amicon Ultra centrifugal filters $3 \mathrm{kDa}$ MWCO (Millipore) at 5,000 $\times \mathrm{g}$ and $4^{\circ} \mathrm{C} .2 \mu \mathrm{g}$ of mouse monoclonal antibody POM2 (A. Aguzzi, Zürich, Switzerland), recognizing repetitive epitopes within the $\mathrm{N}$ terminus of $\mathrm{PrP}^{\mathrm{C}}$, were added to $500 \mu \mathrm{l}$ of concentrated supernatants, and antibody binding was allowed for $16 \mathrm{~h}$ at $4{ }^{\circ} \mathrm{C}$ on a rotating wheel. Protein $\mathrm{G}$ sepharose beads "4 Fast Flow" (GE Healthcare) were washed 3x with RIPA buffer (50 mM Tris- $\mathrm{HCl}$ pH8, $150 \mathrm{mM} \mathrm{NaCl}, 1 \%$ NP40, 0,5\% Na-Deoxycholat, 0,1\% SDS) containing PI. $50 \mu \mathrm{l}$ of a 1:1 suspension of beads in RIPA buffer was then added to the supernatant-antibody solution. After $1 \mathrm{~h}$ of incubation under rotation at $4^{\circ} \mathrm{C}$, complexes were washed with RIPA buffer and boiled for 6 min with $2 \times$ loading buffer. Eluates were subsequently separated from the beads by centrifugation and then subjected to SDS-PAGE as described below.

\section{Western blot analysis of primary neuronal cultures and brain homogenates}

Primary neurons were washed $2 \times$ with ice-cold PBS (PAA laboratories) and then lysed in RIPA buffer containing PI. Centrifugation for $5 \mathrm{~min}$ at $12,000 \times \mathrm{g}$ and $4^{\circ}$ $\mathrm{C}$ was performed to get rid of DNA and cellular debris. Brain homogenates were prepared as described previously [52]. Protein concentrations were determined by Bradford assay (Biorad). For detection of the $\operatorname{PrP}^{\mathrm{C}} \mathrm{C} 1$ fragment, $30 \mu \mathrm{g}$ of total protein was resuspended in digestion buffer (25 mM Tris-HCl pH7.5, 0,5\% SDS, $1 \%$ $\beta$-mercaptoethanol) and boiled for $5 \mathrm{~min} .1 \%$ Nonident P-40 (Fluka) and $5 \mathrm{U}$ of N-glycosidase F (PNGase F; Roche) were added and deglycosylation was allowed for $16 \mathrm{~h}$ at $37^{\circ} \mathrm{C}$. Finally, samples were mixed with $4 \times$ loading buffer $(250 \mathrm{mM}$ Tris- $\mathrm{HCl} \mathrm{pH} 6.8,8 \%$ SDS, $40 \%$ glycerol, $20 \% \beta$-mercaptoethanol, 0,008\% bromphenol blue), boiled for $6 \mathrm{~min}$ at $95^{\circ} \mathrm{C}$, and electrophoretically separated using $12 \%$ Tris/glycine gels. Proteins were transferred to nitrocellulose membranes (Biorad) and detected using mouse monoclonal antibodies to $\operatorname{PrP}^{\mathrm{C}}$ (POM1, 1:2,500 and POM2, 1:5,000; A. Aguzzi, Zürich, Switzerland) or to $\beta$-actin $(1: 5,000$; Sigma), rabbit monoclonal antibody to p53 (1:1,000; Santa Cruz), and rabbit polyclonal antibody to ADAM10 (P. Saftig, Kiel, Germany), as well as the respective anti-mouse or 
anti-rabbit secondary antibodies (1:5,000; Promega). For immunoprecipitated N1 fragment, POM2 was used for pull-down and detection. Blots were developed with SuperSignal West Pico (Pierce). Quantifications were performed using Universal Hood II and Quantity One 4.6.2 software (Biorad).

\section{Generation, nucleofection, and differentiation of neural stem cell cultures}

To derive adherently growing neural stem (NS) cells from ADAM10 cKO mice, we first established neurosphere cultures from the ganglionic eminence of E14 embryos using standard protocols (see e.g. [53]). Neurospheres from the third passage were enzymatically dissociated using Accutase (PAA Laboratories), cells were plated into gelatine-coated tissue culture flasks and further cultivated in NS-A medium (Euroclone) supplemented with $10 \mathrm{ng} / \mathrm{ml}$ fibroblast growth factor-2 (FGF2), $10 \mathrm{ng} / \mathrm{ml}$ epidermal growth factor (EGF) (both from TEBU) and 1\% modified N2 [54]. To express ADAM10 in ADAM10 cKO NS cells, mouse Adam10 cDNA was cloned into pcDNA3.1/Zeo(-) (Invitrogen), and the plasmid was linearized with Bgl II and used to transfect the cells with the Nucleofector ${ }^{\circledR}$ technology (Lonza) as described [55]. Mock transfections were performed with linearized pcDNA3.1/Zeo(-) lacking the Adam10 cDNA. In brief, about $5 \times 10^{6} \mathrm{NS}$ cells were resuspended in $100 \mu \mathrm{l}$ Nucleofector ${ }^{\mathbb{B}}$ solution containing $10 \mu \mathrm{g}$ of linearized DNA, and cells were nucleofected using the Nucleofector ${ }^{\circledR}$ program A033. Transfected cells were plated into tissue culture flasks coated with poly-Lornithine and 1\% Matrigel (Becton Dickinson), and expanded in NS-A containing $10 \mathrm{ng} / \mathrm{ml} \mathrm{FGF-2,} 10 \mathrm{ng} /$ ml EGF, 1\% B27 (Invitrogen), 1\% modified N2 and 200 $\mu \mathrm{g} / \mathrm{ml}$ zeocin. To induce neuronal differentiation of ADAM10- and mock-nucleofected ADAM10 cKO NS cells, cells were first cultivated for four days in NS-A supplemented with $5 \mathrm{ng} / \mathrm{ml} \mathrm{FGF-2,} 2 \%$ B27, and $1 \%$ modified N2, followed by another four days in a 1:1 mixture of NS-A and Neurobasal (Invitrogen) supplemented with $2 \%$ B27 and $0.25 \%$ modified N2. Supernatants from differentiated cultures were collected and subjected to immunoblot analysis.

\section{Sample preparation and immunohistochemical analysis} Embryos were dissected and fixed by immersion in 4\% buffered formalin for $24 \mathrm{~h}$, dehydrated in ascending ethanol concentrations, and embedded in low-meltingpoint paraffin following standard laboratory procedures. $4 \mu \mathrm{m}$ sections were submitted to immunostaining following standard immunohistochemistry procedures using the Ventana Benchmark XT machine (Ventana). Briefly, deparaffinated sections were boiled for $30 \mathrm{~min}$ in CC1 buffer (Ventana) for antigen retrieval. Sections were then incubated with primary antibody POM1 $(1: 100)$ in $5 \%$ goat serum (Dianova), $45 \%$ Tris buffered saline pH7.6, 0,1\% Triton X-100 in antibody diluent solution (Zytomed) for $1 \mathrm{~h}$, followed by detection with Mouse Stain Kit (Nichirei Biosciences) for the detection of murine primary antibodies on murine tissue. Antibody detection was performed with an ultraview universal DAB detection kit (Ventana) followed by counterstaining according to the standard settings of the machine. As negative controls primary antibodies were omitted.

\section{Quantitative RT-PCR}

RNA was extracted from entire brains of E14 $(n=4)$ and P1 ( $\mathrm{n}=3)$ Adam10 cKO and littermate control animals using the NucleoSpin RNAII kit (Macherey Nagel). RNA concentration was determined using the NanoDrop system (Thermo Scientific). First-strand cDNA was synthesized using $1 \mu \mathrm{g}$ of total DNase-treated RNA in a $20 \mu \mathrm{l}$ reverse transcriptase reaction mixture following the instructor manual (High Capacity cDNA Reverse Transcription Kit; Applied Biosystems). All Real-Time PCR reactions were performed in a $10 \mu \mathrm{l}$ mixture containing $10 \mathrm{ng}$ of cDNA preparation $(1 \mu \mathrm{l}), 2 \mathrm{XSYBR}^{\circledR}$ Green PCR Master Mix (Applied Biosystems), and 0.2 $\mu \mathrm{M}$ of each primer. The following primer pairs were used: murine Prnp gene (AATGCTTACCGTGTGACCC; CATGCAGATTCAAAGACCAGC), murine p53 gene (TGGAGAGTATTTCACCCTCAAGA; CTC CTCTGTAGCATGGGCATC), mCdknla (GATCCACAGCGATATCCAGAC; ACCGAAGAGACAACGGCACAC), mMdm2 (TGTCTGTGTCTACCGAGGGTG; TCCAACGGACTTTAACAACTTCA). Real-Time quantitations were performed using the ABS 7500 Fast RealTime PCR System (Applied Biosystems). Fluorescence threshold value was calculated using the 7000 system SDS-software. The Gapdh gene (primers: GGTGAAGG TCGGTGTGAAC; GGGGTCTCGCTCCTGGAA) was used as a reference to compare the relative expression level of target genes.

\section{Immunofluorescence analysis}

Primary neurons were grown on poly-L-Lysine (Sigma) coated coverslips. After washing in PBS, cells were fixed in $4 \%$ paraformaldehyde, washed and treated with $0,1 \mathrm{M}$ glycine solution. Cells were permeabilized using 0,2\% Triton X-100 and unspecific epitopes were blocked with $2 \%$ BSA solution. $\mathrm{PrP}^{\mathrm{C}}$ was detected using POM1 antibody $(1: 200)$ and Alexa Fluor ${ }^{\circledR}$ 488-conjugated donkey anti-mouse secondary antibody (1:500; Invitrogen). For colocalization studies antibodies against PDI (rabbit; 1:100; Stressgen), GM130 (rabbit; 1:50; Abcam), and LAMP1 (rat; 1:50; Hybridoma Bank) were used to visualize ER, Golgi, and lysosomes, respectively. Secondary 
antibodies Alexa Fluor ${ }^{\circledR} 555$ donkey anti-rabbit and anti-rat (Invitrogen) were diluted 1:500. Analysis was performed using an Improvision LiveCell Spinning Disk (Zeiss) or a TCS SP2 confocal microscope (Leica) and Volocity software (Perkin Elmer).

\section{Statistical analysis}

Statistical comparison of Western blot quantifications and qPCR results between A10 cKO and littermate control samples was performed using Student's t-test with consideration of statistical significance at $p$-values $<0,05$ $(*)$ and $<0,01(* *)$.

\section{Additional material}

\section{Additional file 1: (A) Western blot analysis for premature} (pADAM10) and mature ADAM10 (mADAM10; upper row) and $\beta$ actin (lower row) in neuronal cultures from Prnp ${ }^{0 / 0}$, wt, tga20, ADAM10 cKO and littermate controls at E14. Levels of ADAM10 are dramatically reduced in ADAM10 CKO when compared to cultures from littermate controls or from mice overexpressing or lacking PrPC (B) Western blot analysis for PrPC after PNGase F treatment in neuronal lysates from Prnp ${ }^{0 / 0}$, wt, tga20, ADAM10 CKO and littermate controls at E14 showing partially digested full-length prion protein and C1 fragment. (C) Shed PrPC was immunoprecipitated (IP) from culture supernatants of primary neurons derived from Prnp $\%$, wt, tga20, ADAM10 cKO and littermate control mice (all from E14 embryos) and visualized by Western blot analysis for PrPC. Shed full-length PrPC, which shows a 2-3 kDa shift when compared to $\operatorname{PrP}^{C}$ in lysates, is only detectable in wt, tga20, and littermate control neurons. Supernatants from ADAM10 CKO neuronal cultures contain virtually no shed full-length $\operatorname{PrP}^{C}$, whereas the soluble $\mathrm{N} 1$ fragment becomes detectable even in these ADAM10 CKO samples when POM2 is used for pull-down and detection. IgG light chain (IgGLC) of capture antibody is detectable at $25 \mathrm{kDa}$.

\section{Acknowledgements}

We thank Sabine Helbing, Sandra Deutsch, and Martin Haberkorn (University Medical Center Hamburg-Eppendorf) for excellent technical assistance. Antibodies POM1 and POM2 were kindly provided by Adriano Aguzzi (Institute of Neuropathology, University of Zürich, Switzerland).

This work was supported by grants from the Landesexzellenzinitiative Hamburg (SDI-Lexi) to MG; Deutsche Forschungsgemeinschaft (DFG) research training group (1459) to MG and PS; Sonderforschungsbereich (SFB) $877 / 73$ to PS and JP; Leibniz Center for Infection (LCI) graduate school "Model systems for infectious diseases" to HCA and MAK; and a Methusalem grant to BDS.

\section{Author details}

'Institute of Neuropathology, University Medical Center Hamburg-Eppendorf, D-20246 Hamburg, Germany. ${ }^{2}$ Biochemical Institute, Christian-Albrechts University, D-24098 Kiel, Germany. ${ }^{3}$ Department of Tumor Virology, HeinrichPette-Institute for Experimental Virology and Immunology, D-20251 Hamburg, Germany. ${ }^{4}$ Center for Human Genetics, Katholieke Universiteit Leuven, Belguim. ${ }^{5}$ Department for Developmental and Molecular Genetics, Vlaams Instituut voor Biotechnologie (VIB), 3000 Leuven, Belgium. ${ }^{6}$ Department of Ophthalmology, University Medical Center HamburgEppendorf, D-20246 Hamburg, Germany.

\section{Authors' contributions}

The overall study was conceived and designed by $\mathrm{HCA}, \mathrm{BP}$, and MG, with important contributions from PS. HCA, JP, MAK, CB, DT, BP, and UB: performed the experiments. HCA, MAK, and CB: analysed the data. JP, PS, EJ, $B P, U B$, and BDS: contributed reagents, techniques or analysis tools. HCA and
MG wrote the paper with substantial contribution from all co-authors. All authors read and approved the final manuscript.

\section{Competing interests}

The authors declare that they have no competing interests.

Received: 1 April 2011 Accepted: 27 May 2011 Published: 27 May 2011

\section{References}

1. Steele AD, Emsley JG, Ozdinler PH, Lindquist S, Macklis JD: Prion protein $(\mathrm{PrPc})$ positively regulates neural precursor proliferation during developmental and adult mammalian neurogenesis. Proc Natl Acad Sci USA 2006, 103(9):3416-3421.

2. Bremer J, Baumann F, Tiberi C, Wessig C, Fischer H, Schwarz P, Steele AD, Toyka KV, Nave KA, Weis J, et al: Axonal prion protein is required for peripheral myelin maintenance. Nat Neurosci 2010, 13(3):310-318.

3. Sunyach C, Cisse MA, da Costa CA, Vincent B, Checler F: The C-terminal products of cellular prion protein processing, $\mathrm{C} 1$ and $\mathrm{C} 2$, exert distinct influence on p53-dependent staurosporine-induced caspase-3 activation. J Biol Chem 2007, 282(3):1956-1963.

4. Chesebro B, Race B, Meade-White K, Lacasse R, Race R, Klingeborn M, Striebel J, Dorward D, McGovern G, Jeffrey M: Fatal transmissible amyloid encephalopathy: a new type of prion disease associated with lack of prion protein membrane anchoring. PLoS Pathog 2010, 6(3):e1000800.

5. Klingeborn M, Race B, Meade-White KD, Rosenke R, Striebel JF, Chesebro B: Crucial Role for Prion Protein Membrane Anchoring in the Neuroinvasion and Neural Spread of Prion Infection. J Virol 2010.

6. Chen SG, Teplow DB, Parchi P, Teller JK, Gambetti P, Autilio Gambetti L: Truncated forms of the human prion protein in normal brain and in prion diseases. J Biol Chem 1995, 270(32):19173-19180.

7. Hooper NM: Roles of proteolysis and lipid rafts in the processing of the amyloid precursor protein and prion protein. Biochem Soc Trans 2005, 33(Pt 2):335-338.

8. Vincent B, Paitel E, Saftig P, Frobert Y, Hartmann D, De Strooper B, Grassi J, Lopez-Perez E, Checler F: The disintegrins ADAM10 and TACE contribute to the constitutive and phorbol ester-regulated normal cleavage of the cellular prion protein. J Biol Chem 2001, 276(41):37743-37746.

9. Cisse MA, Sunyach C, Lefranc-Jullien S, Postina R, Vincent B, Checler F: The disintegrin ADAM9 indirectly contributes to the physiological processing of cellular prion by modulating ADAM10 activity. J Biol Chem 2005, 280(49):40624-40631.

10. Taylor DR, Parkin ET, Cocklin SL, Ault JR, Ashcroft AE, Turner AJ, Hooper NM: Role of ADAMs in the ectodomain shedding and conformational conversion of the prion protein. J Biol Chem 2009, 284(34):22590-22600.

11. Hattori M, Osterfield M, Flanagan JG: Regulated cleavage of a contactmediated axon repellent. Science 2000, 289(5483):1360-1365.

12. Janes PW, Saha N, Barton WA, Kolev MV, Wimmer-Kleikamp SH, Nievergall E, Blobel CP, Himanen JP, Lackmann M, Nikolov DB: Adam meets Eph: an ADAM substrate recognition module acts as a molecular switch for ephrin cleavage in trans. Cell 2005, 123(2):291-304.

13. Murphy G: The ADAMs: signalling scissors in the tumour microenvironment. Nat Rev Cancer 2008, 8(12):929-941.

14. Hinkle CL, Diestel S, Lieberman J, Maness PF: Metalloprotease-induced ectodomain shedding of neural cell adhesion molecule (NCAM). J Neurobiol 2006, 66(12):1378-1395.

15. Reiss K, Maretzky T, Ludwig A, Tousseyn T, de Strooper B, Hartmann D, Saftig P: ADAM10 cleavage of $\mathrm{N}$-cadherin and regulation of cell-cell adhesion and beta-catenin nuclear signalling. Embo J 2005, 24(4):742-752.

16. Pan D, Rubin GM: Kuzbanian controls proteolytic processing of Notch and mediates lateral inhibition during Drosophila and vertebrate neurogenesis. Cell 1997, 90(2):271-280.

17. Wen C, Metzstein MM, Greenwald I: SUP-17, a Caenorhabditis elegans ADAM protein related to Drosophila KUZBANIAN, and its role in LIN-12/ NOTCH signalling. Development 1997, 124(23):4759-4767.

18. Hartmann D, de Strooper B, Serneels L, Craessaerts K, Herreman A, Annaert W, Umans L, Lubke T, Lena Illert A, von Figura $K$, et al: The disintegrin/metalloprotease ADAM 10 is essential for Notch signalling but not for alpha-secretase activity in fibroblasts. Hum Mol Genet 2002, 11(21):2615-2624.

19. Lieber T, Kidd S, Young MW: kuzbanian-mediated cleavage of Drosophila Notch. Genes Dev 2002, 16(2):209-221. 
20. Lammich S, Kojro E, Postina R, Gilbert S, Pfeiffer R, Jasionowski M, Haass C, Fahrenholz F: Constitutive and regulated alpha-secretase cleavage of Alzheimer's amyloid precursor protein by a disintegrin metalloprotease. Proc Natl Acad Sci USA 1999, 96(7):3922-3927.

21. Jorissen E, Prox J, Bernreuther C, Weber S, Schwanbeck R, Serneels $L$, Snellinx A, Craessaerts $K$, Thathiah A, Tesseur I, et al: The disintegrin/ metalloproteinase ADAM10 is essential for the establishment of the brain cortex. J Neurosci 2010, 30(14):4833-4844.

22. Kuhn PH, Wang H, Dislich B, Colombo A, Zeitschel U, Ellwart JW, Kremmer E, Rossner S, Lichtenthaler SF: ADAM10 is the physiologically relevant, constitutive alpha-secretase of the amyloid precursor protein in primary neurons. Embo J 2010, 29(17):3020-3032.

23. Epis R, Marcello E, Gardoni F, Vastagh C, Malinverno M, Balducci C, Colombo A, Borroni B, Vara H, Dell'Agli M, et al: Blocking ADAM10 synaptic trafficking generates a model of sporadic Alzheimer's disease. Brain 2010, 133(11):3323-3335.

24. Endres K, Mitteregger G, Kojro E, Kretzschmar H, Fahrenholz F: Influence of ADAM10 on prion protein processing and scrapie infectiosity in vivo. Neurobiol Dis 2009, 36(2):233-241.

25. Paitel E, Fahraeus R, Checler F: Cellular Prion Protein Sensitizes Neurons to Apoptotic Stimuli through Mdm2-regulated and p53-dependent Caspase 3-like Activation. J Biol Chem 2003, 278(12):10061-10066.

26. Paitel E, Sunyach C, Alves da Costa C, Bourdon JC, Vincent B, Checler F: Primary cultured neurons devoid of cellular prion display lower responsiveness to staurosporine through the control of p53 at both transcriptional and post-transcriptional levels. J Biol Chem 2004, 279(1):612-618.

27. Menendez D, Inga A, Resnick MA: The expanding universe of p53 targets. Nat Rev Cancer 2009, 9(10):724-737.

28. Prusiner SB: Novel proteinaceous infectious particles cause scrapie. Science 1982, 216(4542):136-144.

29. Aguzzi A, Montrasio F, Kaeser PS: Prions: health scare and biological challenge. Nat Rev Mol Cell Biol 2001, 2(2):118-126.

30. Lauren J, Gimbel DA, Nygaard HB, Gilbert JW, Strittmatter SM: Cellular prion protein mediates impairment of synaptic plasticity by amyloidbeta oligomers. Nature 2009, 457(7233):1128-1132.

31. McMahon HE, Mange A, Nishida N, Creminon C, Casanova D, Lehmann S: Cleavage of the amino terminus of the prion protein by reactive oxygen species. J Biol Chem 2001, 276(3):2286-2291.

32. Parkin ET, Watt NT, Turner AJ, Hooper NM: Dual mechanisms for shedding of the cellular prion protein. J Biol Chem 2004, 279(12):11170-11178.

33. Watt NT, Taylor DR, Gillott A, Thomas DA, Perera WS, Hooper NM: Reactive oxygen species-mediated beta-cleavage of the prion protein in the cellular response to oxidative stress. J Biol Chem 2005, 280(43):35914-35921

34. Parkin ET, Watt NT, Hussain I, Eckman EA, Eckman CB, Manson JC, Baybutt HN, Turner AJ, Hooper NM: Cellular prion protein regulates betasecretase cleavage of the Alzheimer's amyloid precursor protein. Proc Natl Acad Sci USA 2007, 104(26):11062-11067.

35. Liang J, Parchaliuk D, Medina S, Sorensen G, Landry L, Huang S, Wang M, Kong Q, Booth SA: Activation of p53-regulated pro-apoptotic signaling pathways in PrP-mediated myopathy. BMC Genomics 2009, 10:201.

36. Vincent B, Sunyach C, Orzechowski HD, St George-Hyslop P, Checler F: p53Dependent transcriptional control of cellular prion by presenilins. $J$ Neurosci 2009, 29(20):6752-6760.

37. Weiss E, Ramljak S, Asif AR, Ciesielczyk B, Schmitz M, Gawinecka J, SchulzSchaeffer W, Behrens C, Zerr I: Cellular prion protein overexpression disturbs cellular homeostasis in SH-SY5Y neuroblastoma cells but does not alter p53 expression: a proteomic study. Neuroscience 2010, 169(4):1640-1650.

38. Walmsley AR, Watt NT, Taylor DR, Perera WS, Hooper NM: alpha-cleavage of the prion protein occurs in a late compartment of the secretory pathway and is independent of lipid rafts. Mol Cell Neurosci 2009, 40(2):242-248.

39. Shmerling D, Hegyi I, Fischer M, Blattler T, Brandner S, Gotz J, Rulicke T, Flechsig E, Cozzio A, von Mering C, et al: Expression of amino-terminally truncated $\operatorname{PrP}$ in the mouse leading to ataxia and specific cerebellar lesions. Cell 1998, 93(2):203-214.

40. Radovanovic I, Braun N, Giger OT, Mertz K, Miele G, Prinz M, Navarro B, Aguzzi A: Truncated prion protein and Doppel are myelinotoxic in the absence of oligodendrocytic PrPC. J Neurosci 2005, 25(19):4879-4888.
41. Li A, Piccardo P, Barmada SJ, Ghetti B, Harris DA: Prion protein with an octapeptide insertion has impaired neuroprotective activity in transgenic mice. Embo J 2007, 26(11):2777-2785.

42. Guillot-Sestier MV, Sunyach C, Druon C, Scarzello S, Checler F: The alphasecretase-derived $\mathrm{N}$-terminal product of cellular prion, N1, displays neuroprotective function in vitro and in vivo. J Biol Chem 2009, 284(51):35973-35986.

43. Rivera-Milla E, Oidtmann B, Panagiotidis CH, Baier M, Sklaviadis T, Hoffmann R, Zhou Y, Solis GP, Stuermer CA, Malaga-Trillo E: Disparate evolution of prion protein domains and the distinct origin of Doppeland prion-related loci revealed by fish-to-mammal comparisons. Faseb J 2006, 20(2):317-319.

44. Jimenez-Huete A, Lievens PM, Vidal R, Piccardo P, Ghetti B, Tagliavini F, Frangione B, Prelli F: Endogenous proteolytic cleavage of normal and disease-associated isoforms of the human prion protein in neural and non-neural tissues. Am J Pathol 1998, 153(5):1561-1572.

45. Oliveira-Martins JB, Yusa S, Calella AM, Bridel C, Baumann F, Dametto P, Aguzzi A: Unexpected tolerance of alpha-cleavage of the prion protein to sequence variations. PLOS ONE 2010, 5(2):e9107.

46. Laffont-Proust I, Faucheux BA, Hassig R, Sazdovitch V, Simon S, Grassi J, Hauw JJ, Moya KL, Haik S: The N-terminal cleavage of cellular prion protein in the human brain. FEBS Lett 2005, 579(28):6333-6337.

47. Anderegg $U$, Eichenberg T, Parthaune T, Haiduk C, Saalbach A, Milkova L, Ludwig A, Grosche J, Averbeck M, Gebhardt C, et al: ADAM10 is the constitutive functional sheddase of CD44 in human melanoma cells. J Invest Dermatol 2009, 129(6):1471-1482.

48. Tronche F, Kellendonk C, Kretz O, Gass P, Anlag K, Orban PC, Bock R, Klein R, Schutz G: Disruption of the glucocorticoid receptor gene in the nervous system results in reduced anxiety. Nat Genet 1999, 23(1):99-103.

49. Büeler HR, Fischer M, Lang Y, Bluethmann H, Lipp HP, DeArmond SJ, Prusiner SB, Aguet M, Weissmann C: Normal development and behaviour of mice lacking the neuronal cell-surface PrP protein. Nature 1992, 356:577-582.

50. Fischer M, Rülicke T, Raeber A, Sailer A, Moser M, Oesch B, Brandner S, Aguzzi A, Weissmann C: Prion protein (PrP) with amino-proximal deletions restoring susceptibility of PrP knockout mice to scrapie. EMBO J 1996, 15(6):1255-1264.

51. Annaert WG, Levesque L, Craessaerts K, Dierinck I, Snellings G, Westaway D, George-Hyslop PS, Cordell B, Fraser P, De Strooper B: Presenilin 1 controls gamma-secretase processing of amyloid precursor protein in pre-golgi compartments of hippocampal neurons. J Cell Biol 1999, 147(2):277-294.

52. Glatzel M, Heppner FL, Albers KM, Aguzzi A: Sympathetic innervation of lymphoreticular organs is rate limiting for prion neuroinvasion. Neuron 2001, 31(1):25-34.

53. Ader M, Meng J, Schachner M, Bartsch U: Formation of myelin after transplantation of neural precursor cells into the retina of young postnatal mice. Glia 2000, 30(3):301-310.

54. Conti L, Pollard SM, Gorba T, Reitano E, Toselli M, Biella G, Sun Y, Sanzone S, Ying QL, Cattaneo $E$, et al: Niche-independent symmetrical self-renewal of a mammalian tissue stem cell. PLOS Biol 2005, 3(9):e283.

55. Richard I, Ader M, Sytnyk V, Dityatev A, Richard G, Schachner M, Bartsch U: Electroporation-based gene transfer for efficient transfection of neural precursor cells. Brain Res Mol Brain Res 2005, 138(2):182-190.

doi:10.1186/1750-1326-6-36

Cite this article as: Altmeppen et al:: Lack of a-disintegrin-andmetalloproteinase ADAM10 leads to intracellular accumulation and loss of shedding of the cellular prion protein in vivo. Molecular Neurodegeneration $20116: 36$. 